\title{
ASSESSMENT OF SELECTED PHYSICO-CHEMICAL PARAMETERS OF GROUND WATER IN DIRECT CONTACT WITH SEPTIC TANKS: EXPERIMENTAL MODELING
}

\author{
Shawkat Ahmed Yaseen Kochary, Bahzad Mohammad Ali NoORI ${ }^{*}$ and TOM D. BYL ${ }^{* *}$ \\ Dept. of Civil Engineering, University of Duhok, Kurdistan Region-Iraq \\ *Dept. of Agriculture Sciences, Tennessee State University-USA.
}

\begin{abstract}
The purpose of this study was to assess the effect of non-regulated (and directly contacted) septic tanks on ground water quality through designing a laboratory physical vadose model (PVM) with a vertical flow direction. The model was packed with silt-Clay soil using a new packing approach other than the ordinary (standard, modified and static) compaction methods, which was adopted upon its homogeneity and efficiency approval. The effect of septic tanks as an exclusive source of contaminants was represented by supplying the designed model with newly collected septic water (black water from a septic tank). Preliminary in-situ soil tests were conducted to better represent the lithology of area of this study. The model was run for a period of three months and water samples were collected on daily basis however, weekly analyzed. Selected physical and chemical parameters were studied for assessment including pH, Temperature, Dissolved Oxygen (DO), Electrical Conductivity (EC), Total Hardness (TH), Ammonium $\left(\mathrm{NH}_{4}-\mathrm{N}\right)$, Nitrate $\left(\mathrm{NO}_{3}{ }^{-} \mathrm{N}\right)$, and Phosphorus (P). Analytical results were used to identify and model trends to estimate and predict future trends, which mostly led to a conclusion of bad category and very low ground water quality as a result of its direct contact with non-regulated septic tanks. This study helped the local government in establishing precaution strategies for ground water management in order to protect the public health.
\end{abstract}

KEYWORDS: Septic Tanks, Ground Water, Physical Vadose Model (PVM), Physico-Chemical Parameters

\section{INTRODUCTION}

$\mathrm{W}$ ater (the blue gold) is the most important element needed for survival and fundamental to human well-being that cannot afford to live without. It is a finite, irreplaceable but renewable if well managed (the average renewal time of the ground water is 1400 years (Korzoun, V. and Sokolov, A., 1978), and it exists naturally in all physical (liquid, solid, and gas) form with unique chemical and physical properties that make it essential for life. With world population growth and limited access to clean drinking water, ground water was and still an alternative source in many areas around the world for people to rely on to secure their needs, but simply being the water underground does not mean it is safe, but that makes it more vulnerable to surrounding environment and human activities. Pollution becomes a major environmental concern with potential for depletion and degradation of ground water, and when contaminated, it will be very difficult and costly to clean.

The most serious threat to human health and the environment according to United States environmental protection agency (USEPA), is the contamination of ground water (Holland, 1992), while the most frequently reported cause of ground water contamination related to water-borne diseases out breaks by bacteria and viruses are septic systems (Yates, 1985). As many cases of ground water contamination and water-related diseases have reported, the public (who rely on the ground water supply) became more concern about ground water quality by septic systems. Therefore, this research was conducted to assess the quality of regional ground water of Duhok city in direct contact with non-regulated septic tanks through assessing selected physico-chemical parameters of ground water of in order to protect the public health as well as the environment.

\section{DESIGN OF PHYSICAL EXPERIMENTAL MODEL}

\subsection{Preliminary Tests}

A soil specimen from a non-residential area was collected and necessary preliminary tests were performed in order to specify soil properties that play a good role in biodegrading the contaminants and their transportation through soil 
profile to be represented in the designed experimental model. These tests included in-situ bulk and dry densities for undisturbed soil using (ASTM D1556) method, hydrometer analysis using (ASTM D422) method, atterberg limits by (ASTM D4318) method, optimum water content with optimum dry density (ASTM D-698) method, permeability test (falling-head method), and specific gravity test using (ASTM D854) method. The soil used as packing material was classified as Low plasticity Clay soil (CL) according to unified soil classification system plasticity chart for laboratory classification of fine-grained soil. Results of preliminary tests were listed in Table 1. The permeability coefficient factor (k) of tasted soil was within the permeability range of clay to silt-Clay soil $\left(10^{-8}\right.$ -
$10^{-5} \mathrm{~mm} / \mathrm{sec}$ ) and its specific gravity was within the range of clay to silt clay soil (2.68 to 2.80) according to Das, (2013).

To conduct this study, it was proposed to design an experimental model, packed with siltClay soil, and run with septic water (from a septic tank) as exclusive source contaminants. To ensure collecting water samples, $20 \%$ (by weight) of packing material was replaced with fine sand, which particles passed sieve \#30 and remained on sieve \#40 to increase the hydraulic conductivity. The porosity of packed material (silt-Clay soil) was 0.354 and for dry sand was 0.346 , which both were within the soil property limits (Zhang, 2011). Actual hydraulic conductivity of new packed material after texture modification was $\mathrm{k}_{\text {act }}=1.79$ $\begin{array}{lll}\mathrm{x} & 10^{-4} & \mathrm{~cm} / \mathrm{sec} \text {. }\end{array}$

Table (1): -Specifications of packing material

\begin{tabular}{ccc}
\hline No & Soil Parameter & Value / Unit \\
\hline 1 & In-situ bulk density & $20.14 \mathrm{kN} / \mathrm{m}^{3}$ \\
\hline 2 & In-situ dry density & $17.18 \mathrm{kN} / \mathrm{m}^{3}$ \\
\hline 3 & Liquid limit & $34.5 \%$ \\
\hline 4 & Plastic limit & $22.3 \%$ \\
\hline 5 & Plasticity index & $12.2 \%$ \\
\hline 6 & Optimum water content & $18.5 \%$ \\
\hline 8 & Maximum dry density & $1725 \mathrm{~kg} / \mathrm{m}^{3}$ \\
\hline 9 & Permeability coefficient factor $(\mathrm{k})$ & $0.044 \times 10^{-5} \mathrm{~cm} / \mathrm{sec}$ \\
\hline 10 & Specific gravity & 2.71 \\
\hline
\end{tabular}

\subsection{Physical Modeling}

A large-scaled (1:50) physical model was designed with vertical flow direction. The frame of model was made of 3-inch tapered edge $\mathrm{L}$ steel angle with external dimensions of $212 \mathrm{~cm}$ height $\mathrm{x}$ $123.5 \mathrm{~cm}$ width $\times 11.2 \mathrm{~cm}$ depth. Four galvanized hex bolts of $(10 \mathrm{~mm} \times 180 \mathrm{~mm})$ supported the body of model. The model net internal dimensions were $210 \mathrm{~cm}$ height $\times 122 \mathrm{~cm}$ width $\times 9.7 \mathrm{~cm}$ depth. The model walls have made from Perspex Acrylic sheets of $6 \mathrm{~mm}$ thickness, which were roughened from inside to eliminate the effect of smooth boundaries and lined to quantify packing material for desired density satisfaction.

Eight sampling ports with $2 \times 2 \times 9.5 \mathrm{cms}$ were made of perforated acrylic material, dressed by knitted filter socks, and installed at levels 12.5,
37.5, 62.5, 87.5, 112.5, 137.5, 162.5, and $187.5 \mathrm{cms}$ and labeled as Port A, Port B, Port C, Port D, Port E, Port F, Port G and Port H respectively. The interested port for this study was port $\mathrm{C}$, which located at $62.5 \mathrm{cms}$ from the top of model, which represented a ground water level of $31.25 \mathrm{~m}$ underground. Piezometers have installed at sampling port levels in order to monitor the hydraulic gradient and model internal pressure. A tank of $122 \mathrm{~cm}$ length $\times 6 \mathrm{~cm}$ thick $\times 6 \mathrm{~cm}$ depth with five openings of $4 \times 6 \mathrm{~cm}$ for width and length was designed, constructed (as a storage chamber of septic tanks), and put on top of the model. Figure (1) is a sketch of experimental model and Figure (2) represent a physical experimental model of 1:50 scale. 


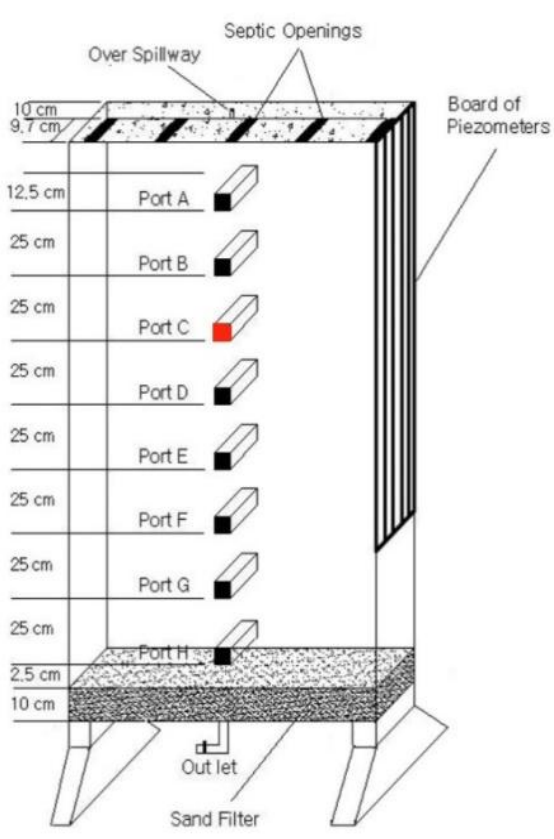

Fig. (1) Sketch of Experimental Model

\subsection{Design of Drain Filter}

To improve flow conditions and prevent fine graded materials from permeation out of the model, a drain filter was designed. In designing drain filters and envelopes, (Bertram, 1940) and (Ministry of Agriculture and Food, British Columbia, 2000) have established the validity of two criteria.

$$
\begin{aligned}
& \text { 1. } \frac{\text { D15 (filter) }}{\text { D15 (base) }} \geq 4 \text { to } 5 \\
& \text { 2. } \frac{\text { D15 (filter) }}{\text { D85 (base) }}<4 \text { to } 5
\end{aligned}
$$

$D_{15}$ is grain size for which 15 percent of the material, by weight, is finer, and $\mathrm{D}_{85}$ is grain size for which 85 percent of material (by weight), is finer. Upon satisfaction of all conditions and criteria, the drain filter has designed, homogeneously mixed, and provided as one layer of 100 millimeter to the bottom of model. For more details on deigning the drain filter, refer to (Kochary, S., 2017).

\subsection{Model Packing}

The model was packed with $377.5 \mathrm{kgs}$ of $20 / 80$ percent (by weight) of sand/clay mixture with average dry density of $17.12 \mathrm{kN} / \mathrm{m}^{3}$. A new packing procedure was implemented (other than the ordinary standard, modified, and static compaction methods). The new adopted packing procedure was found efficient and summarized in the following:

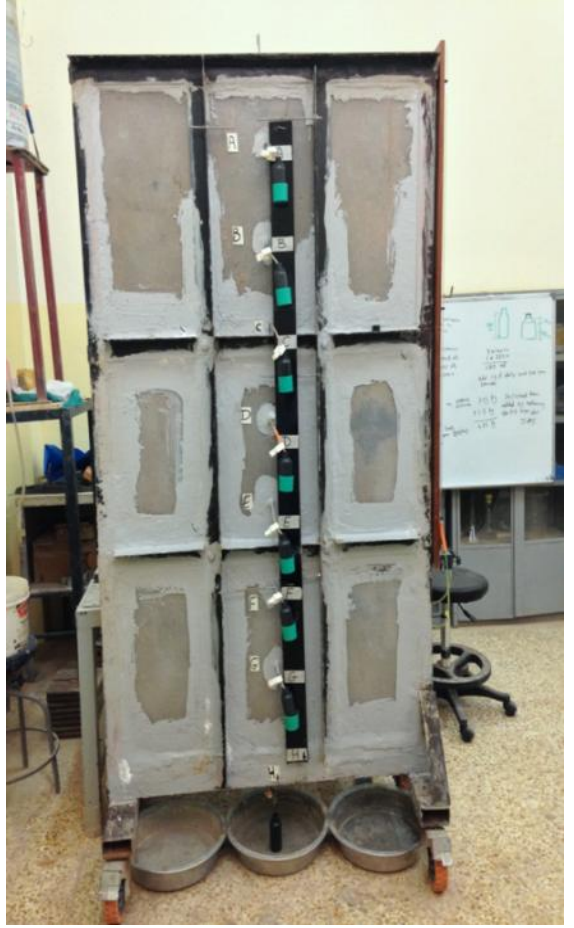

Fig. (2) Physical Experimental Model

The model is to be filled with tap water to 20$30 \mathrm{cms}$, a known amount of packing material is to spread uniformly into the water (over all model cross section) and to gently pushed down (to avoid breaking the bonds of soil particles) until it reaches the designated line (that satisfies the desired soil density). The resulted turbid water left in the model is to be replaced with another (20$30 \mathrm{cms}$ ) depth of clean tap water for next layer. The process is to be repeated until model packing process complete. For more details, refer to (Kochary, S., 2017).

\subsection{Model Draining Process}

The model was drained from dissolved material contents for a period of four weeks using tap water with steady state flow condition (flow in =flow out), which was maintained by installing an over spillway at $4 \mathrm{cms}$ water head level inside the inflow chamber on top of the model. Draining process continued until the electrical conductivity of water inlet and outlet has reached a negligible level of difference $\left(\mathrm{EC}_{\text {in }} \approx \mathrm{EC}_{\text {out }}\right)$.

\section{METHODS OF ANALYSIS AND INSTRUMENTS USED}

Very new (recent) septic water was collected from a septic tank, filtered twice to remove suspended materials, packed into plastic bottles of 1.5-liter, and refrigerated at $4{ }^{\circ} \mathrm{c}$ in the dark. For steady-state flow condition satisfaction, a bottle of 
septic water was added to the model daily, and within four hours, a set of $8 \times 180 \mathrm{ml}$ samples from all sampling ports were collected. On weekly basis, collected water samples were analyzed for selected physical and chemical parameters mostly following the standard methods (Standard Methods, 1996). The parameters included $\mathrm{pH}$, Temperature (T), Dissolved Oxygen (DO), and Electrical Conductivity (EC), which determined immediately upon sample collection using the portable Horiba U-10 water quality meter. Collected water samples were then refrigerated at $4^{\circ} \mathrm{c}$ without adding any preservatives for later analysis, which included Total Hardness (TH), Ammonium ion $\mathrm{NH}_{4}-\mathrm{N}$ and Nitrate $\mathrm{NO}_{3}^{-1}$ ion, and
Phosphorus (P). Total Hardness (TH) was assessed by determining the concentration of Calcium ion $\left(\mathrm{Ca}^{++}\right)$and Magnesium ion $\left(\mathrm{Mg}^{++}\right)$ using flame atomic absorption spectrophotometer FAAS, Ammonium ion $\mathrm{NH}_{4}-\mathrm{N}$ and Nitrate $\mathrm{NO}_{3}^{-1}-$ $\mathrm{N}$ ion were determined by Kjeldahl method (ASTM D-3590-02), and Phosphorus (P) was determined using ammonium vanadium method as mentioned by

\section{RESULTS AND DUSCUSSION}

The results of port $\mathrm{C}$ of designed model that represents the ground water at $31.25 \mathrm{~m}$ underground overall running processes were listed in Table 2.

Table (2):- Collective of physical and chemical parameters data overall model running process

\begin{tabular}{ccccccccccc}
\hline $\begin{array}{c}\text { Time } \\
\text { (Days) }\end{array}$ & $\mathbf{p H}$ & $\begin{array}{c}\text { Temp } \\
\mathbf{C} \mathbf{0}\end{array}$ & $\begin{array}{c}\mathbf{D . O} \\
\mathbf{m g} / \mathbf{l}\end{array}$ & $\begin{array}{c}\mathbf{E C} \\
\mathbf{m S} / \mathbf{c m}\end{array}$ & $\begin{array}{c}\mathbf{C a} \\
\mathbf{m g} / \mathbf{l}\end{array}$ & $\begin{array}{c}\mathbf{M g}^{++} \\
\mathbf{m g} / \mathbf{l}\end{array}$ & $\begin{array}{c}\mathbf{T} . \mathbf{H} \\
\mathbf{m g} / \mathbf{l}\end{array}$ & $\begin{array}{c}\mathbf{N H}_{4}-\mathbf{N} \\
\mathbf{m g} / \mathbf{l}\end{array}$ & $\begin{array}{c}\mathbf{N O}_{3}-\mathbf{N} \\
\mathbf{m g} / \mathbf{l}\end{array}$ & $\begin{array}{c}\mathbf{P} \\
\mathbf{m g} / \mathbf{l}\end{array}$ \\
\hline 0 & 7.1 & 25.1 & 4.01 & 0.46 & 22.59 & 30.73 & 182.86 & 0.357 & 11.2 & 0.043 \\
\hline 7 & 6.7 & 27.2 & 3.87 & 1.67 & 91.25 & 100.33 & 640.71 & 0.114 & 14 & 0.031 \\
\hline 14 & 6.8 & 24.2 & 4.86 & 2.35 & 100.68 & 128.12 & 778.61 & 0.200 & 16.8 & 0.105 \\
\hline 21 & 6.9 & 25.7 & 3.25 & 2.65 & 106.01 & 102.31 & 685.71 & 0.214 & 16.8 & 0.095 \\
\hline 28 & 7.0 & 25.2 & 7.18 & 2.83 & 105.56 & 160.28 & 923.14 & 0.386 & 16.8 & 0.044 \\
\hline 35 & 7.0 & 23 & 16.05 & 2.71 & 99.71 & 163.56 & 922.03 & 0.329 & 14 & 0.138 \\
\hline 42 & 7.2 & 22.3 & 18.89 & 2.69 & 104.67 & 187.18 & 990.46 & 0.229 & 11.2 & 0.085 \\
\hline 49 & 6.9 & 21.3 & 9.33 & 2.72 & 72.5 & 116.85 & 661.87 & 0.200 & 2.8 & 0.070 \\
\hline 56 & 7.0 & 21.8 & 7.03 & 2.63 & 74.34 & 130.56 & 722.88 & 0.186 & 2.8 & 0.079 \\
\hline 63 & 7.1 & 21.9 & 2.41 & 2.67 & 65.34 & 129.51 & 696.09 & 0.171 & 1.96 & 0.185 \\
\hline 70 & 7.0 & 22.2 & 5.37 & 2.55 & 68.71 & 129.12 & 702.9 & 0.129 & 2.24 & 0.390 \\
\hline 77 & 6.9 & 23.4 & 2.84 & 2.56 & 93.73 & 119.27 & 724.84 & 0.100 & 2.24 & 0.555 \\
\hline 84 & 6.8 & 23.3 & 2.79 & 2.53 & 93.86 & 116.96 & 715.66 & 0.229 & 2.24 & 0.536 \\
\hline 91 & 7.1 & 21.1 & 13.28 & 1.89 & 84.35 & 110.04 & 663.44 & 0.129 & 2.8 & 0.667 \\
\hline
\end{tabular}

$\mathrm{pH}$ : Is a measure of degree of acidity or basicity of a solution under normal conditions of pressure and temperature. Hence, it uses to identify the condition of a solution, and $\mathrm{pH}$ of a soil is the measure of hydrogen ions concentration in soil water. Aquatic life are very sensitive to $\mathrm{pH}$ level and has a big effect on all body's chemistry and health. It controls the chemical state of many nutrients like dissolved oxygen, phosphate, nitrate, etc. (Parashar et al., 2006). Although most of water resources are slightly acidic, (WHO, 2004) recommends $\mathrm{pH}$ permissible range of 6.5 to 9.2, which beyond that, it can affect cells membrane and cause corrosiveness to water supply systems. This study revealed that throughout model running process, $\mathrm{pH}$ values was within the desirable limits (Figure 3). It ranged from 6.1 to 7.2 with mean of 6.96 suggesting that the soil used in packing the model has a good buffering capacity (the ability of soil to resist the changes in $\mathrm{pH}$ ). 


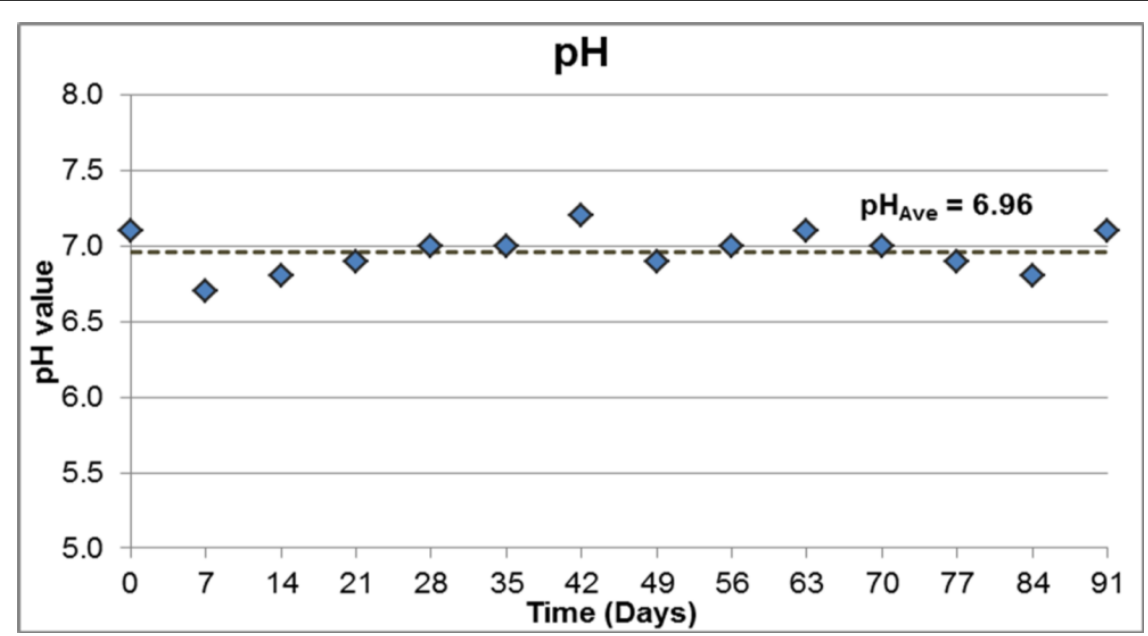

Fig. (3): -pH values all over model running process

Temperature: The change of temperature, In general, effect the living organisms. The growth rate of microorganisms increases by increasing the temperature as high temperature accelerates the chemical and biological processes in the water resulting in reduction of its ability to hold the essential dissolved gases like oxygen. In addition, At high temperatures, disinfectants act more rapidly. While conducting this research, model temperature all over running process was at average of $23.4 \mathrm{C}^{\circ}$ (Figure 4) .

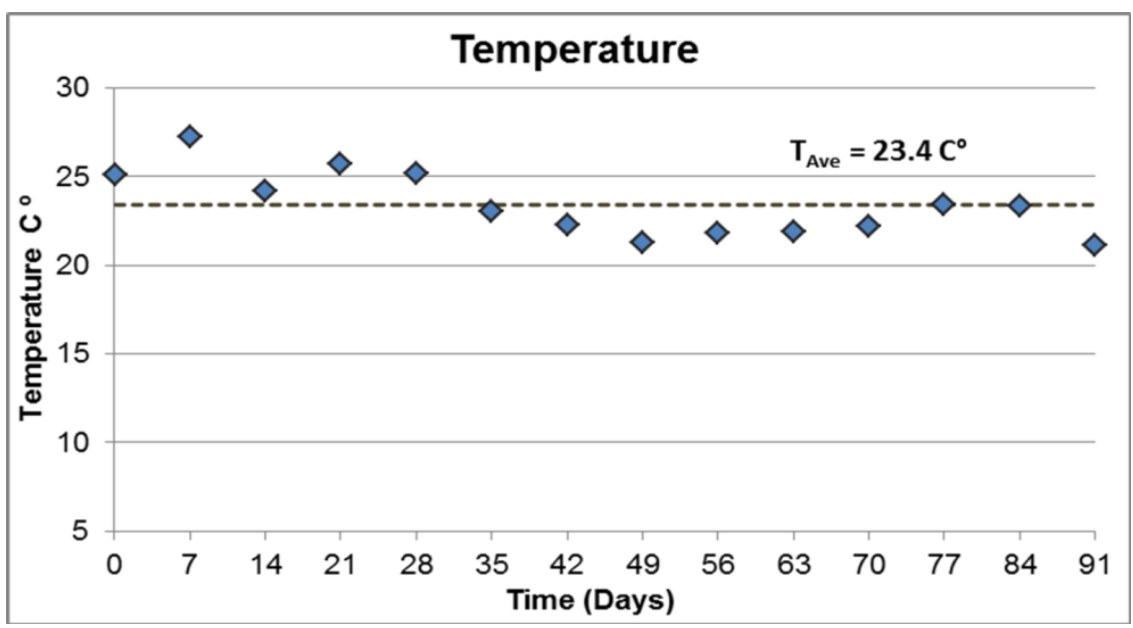

Fig. (4):- Model temperature all over running process

Dissolved Oxygen: The amount of dissolved oxygen in water is expressed as a concentration (amount in weight). It is commonly expressed as milligrams per liter $(\mathrm{mg} / \mathrm{L})$ or as parts per million $(\mathrm{ppm})$. The test of dissolved oxygen measures the amount of gaseous oxygen $\left(\mathrm{O}_{2}\right)$ dissolved in an aqueous solution (water) that sustain the life below which is stressful to most aquatic organism. Many factors affect the concentration of dissolved oxygen in water among which 1.Temperature: Oxygen is more easily dissolved in cold water (As the water temperature increases, the amount of dissolved oxygen decreases). 2. The amount of total dissolved solids (Oxygen dissolves easier into water with low content of dissolved solids). 3 .
Sewage and industrial discharges (Organic wastes, septic tanks) as bacterial decomposition of organic matter consumes a great deal (decreases level) of oxygen in the water. Under normal conditions of salinity, pressure and temperature, natural water contains 5 to $14.5 \mathrm{mg} / \mathrm{L}$ of dissolved oxygen (Jadhav et al,. 2013). Dissolved oxygen is the factor that determines whether biological changes are brought by aerobic or anaerobic organisms. Therefore, measuring the dissolved oxygen is vital to maintain the aerobic treatment processes of domestic and industrial wastewater. The optimum value for good water quality is 4 to $6 \mathrm{mg} / \mathrm{L}$ of DO, which ensures healthy aquatic life in a water body (Jadhav et al,. 2013). In general, DO levels of less 
than $3 \mathrm{mg} / \mathrm{L}$ are stressful to most aquatic organisms, DO from 2 to $0.5 \mathrm{mg} / \mathrm{L}$ are considered hypoxic, and waters with less than $0.5 \mathrm{mg} / \mathrm{L}$ are anoxic (Missouri Department of Natural Resources). WHO has set $5 \mathrm{mg} / \mathrm{L}$ for dissolved oxygen of drinking water. This study revealed that septic water has caused a very critical situation with respect to dissolved oxygen. Dissolved Oxygen has reached the value of $9.33 \mathrm{mg} / \mathrm{L}$ on week 7 .However, It decreased according the poly2 relation of (Figure 5) until it reached $0.227 \mathrm{mg} / \mathrm{L}$ by the end of running the model (week 11 ), which considers anoxic. This is an alarming sign to be considered immediately.

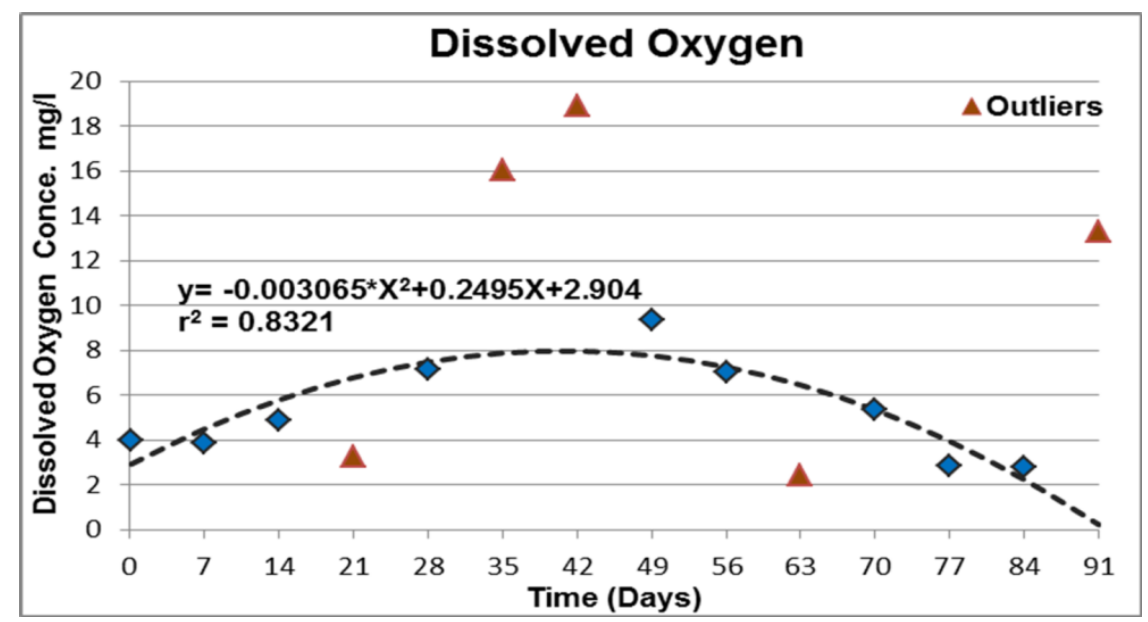

Fig.(5): -Dissolved oxygen concentration all over model running process

Electrical Conductivity (EC): Is the ability of water to conduct (or carry and convey) the electrical current by its ionic content. It measures in milli-Siemens $(\mathrm{ms} / \mathrm{cm})$ or micro-Siemens per centimeter $(\mu \mathrm{s} / \mathrm{cm})$. It is a key parameter in determining the suitability of water for a particular purpose (drinking or others) as it provides a rapid indication of total dissolved solids (TDS) contents. Electrical conductivity and total dissolved solids (TDS) are convertible to each other using this equation: TDS $(\mathrm{mg} / \mathrm{L}$ or $\mathrm{ppm})=0.64 \mathrm{x} \mathrm{EC}$ $(\mu \mathrm{S} / \mathrm{cm})$ (Deshpande, S. and Aher, K., 2012). Electrical conductivity of water increases $2-3 \%$ per $1^{\circ} \mathrm{c}$ increase of water temperature, while for pure water; it increases approximately $5 \%$ per $1{ }^{\circ} \mathrm{C}$ (Zaidi, J. and Pal, A., 2015) For drinking water,
WHO has set $0.75-1.5 \mathrm{~ms} / \mathrm{cm}$ for electrical conductivity (WHO, 1995) and $1000 \mathrm{mg} / \mathrm{L}$ for total dissolved solids (WHO, 2006). Our study revealed that EC values were above the permissible level all over model running process with mean of $2.35 \mathrm{~ms} / \mathrm{cm}$ and it increases according to the equation $\mathrm{y}=0.3386 \operatorname{Ln}(\mathrm{x})+1.317$ (Figure 6). The high values of EC may be attributed to high salts contents in septic water used in running the model rather than its contents in the soil itself as the initial value of EC before running the model was $0.46 \mathrm{~ms} / \mathrm{cm}$ which, was much lower than the permissible level suggesting that septic water causes a critical situation with respect to electrical conductivity that require septic tanks improvement. 


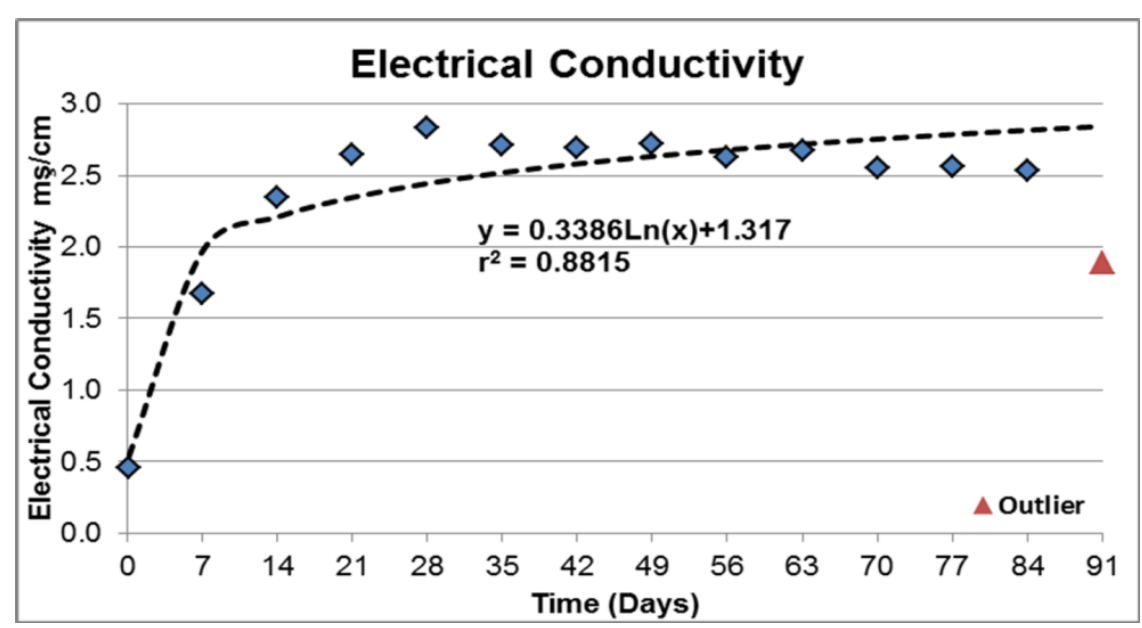

Fig. (6):- Electrical conductivity all over model running process

Total Hardness (T.H): Is a very important parameter in decreasing the toxic effects of poisonous elements. T.H of water is a measure of total amount of divalent metallic cations of calcium and magnesium. It usually expressed in term of milligrams per liter (or ppm) of calcium carbonate $\left(\right.$ as $\mathrm{CaCO}_{3}$ ) in water. Total hardness may be calculated using the equation: $\mathrm{T} . \mathrm{H}=2.497$ $\mathrm{x} \mathrm{Ca}^{+2}+4.115 \mathrm{x} \mathrm{Mg}^{+2}$, where all units are in $\mathrm{ppm}$ (Brindha, K. and Elango, L., 2011). There are two types of water hardness; temporary hardness (when carbonates $\mathrm{CO}_{3}{ }{ }^{\text {and bi-carbonates }} \mathrm{HCO}_{3}{ }^{-}$ of calcium and magnesium are present in water) and permanent hardness (when sulphates, chlorides and nitrates of calcium and magnesium are present in water). Temporary hardness is removable by either boiling the water or by adding lime to it while the permanent hardness may be removed but by using ion exchange column or water softening methods. (WHO, 1995) has set $500 \mathrm{mg} / \mathrm{L}$ as a permissible limit for total hardness for drinking water. This study revealed that throughout model running process, total hardness were much above the permissible level with mean of $715.1 \mathrm{mg} / \mathrm{L}$ and it is in continuous accumulation following the equation $\mathrm{y}=74.09$ $\operatorname{Ln}(\mathrm{x})+400.5$ (Figure 7). The high values of T.H may be attributed to high concentration of both calcium and magnesium salts in septic water suggesting the septic tanks to be regulated and improved.

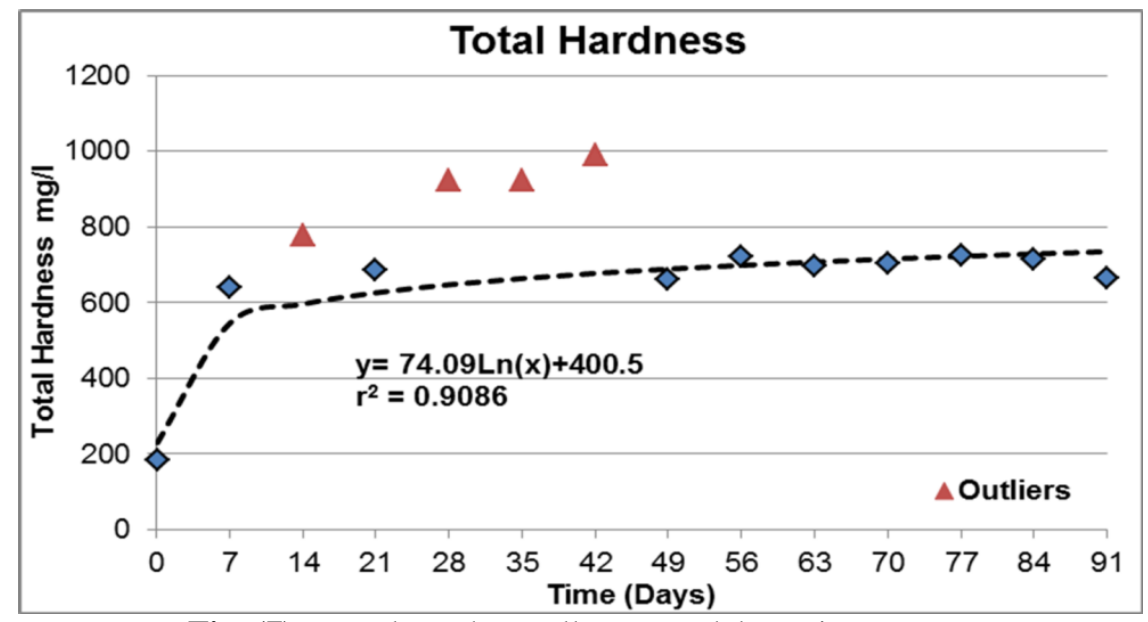

Fig. (7):- Total Hardness all over model running process

Ammonium, as $\mathrm{N}$ (NH4-N): Is a nitrogen compound which is colorless and readily soluble in water. In the aquatic environment, ammonia assumes two chemical forms: NH4+ - (ionized) 
and NH3 - (unionized) form. The ionized form is nontoxic or has less toxicity than the unionized form, which has a high toxic nature. In aqueous solution, ammonia acts as a base, gaining hydrogen ions from $\mathrm{H} 2 \mathrm{O}$ to yield ammonium and hydroxide ions. NH3 (aq) + $\mathrm{H} 2 \mathrm{O}(\mathrm{l})$ <--> $\mathrm{NH} 4+(\mathrm{aq})+\mathrm{OH}-(\mathrm{aq})$. Total ammonia nitrogen in a solution is the sum of these two forms i.e. $(\mathrm{NH} 3 \mathrm{~N}+\mathrm{NH} 4 \mathrm{~N}) . \mathrm{N}$ at the end of these parameters suggests their expression based on the mass of Nitrogen. The US Environmental Protection Agency (USEPA) has not established a maximum contaminant level (MCL) for ammonia in drinking water. However, the level of ammonium nitrogen in drinking water should not exceed $0.5 \mathrm{mg} / \mathrm{L}$ (Lipponen et al., 2004). Our study revealed that throughout model running process, the concentrations of ammonium nitrogen were lower than the permissible level with mean of $0.212 \mathrm{mg} /$ $\mathrm{L}$ and the concentration decreases (with time) following the equation $y=1.292 \mathrm{e}-05 \mathrm{X}^{2}$ $0.003249 \mathrm{X}+0.3084$ (Figure 8) suggesting that septic tanks of study area has no negative effect on the quality of drinking water with reference to ammonium nitrogen.

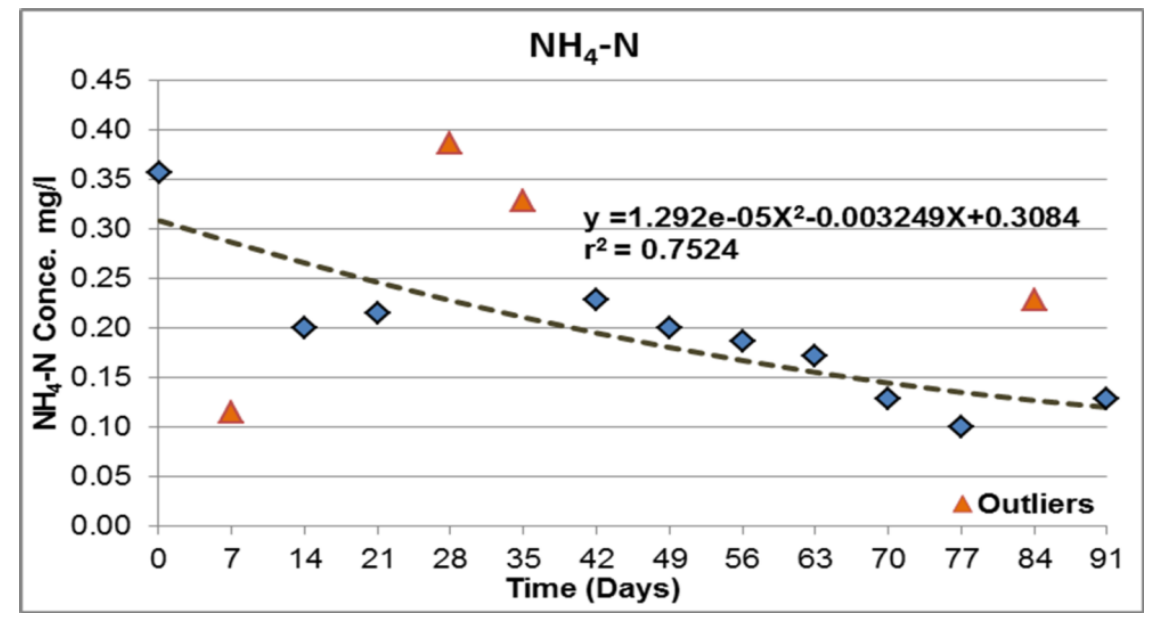

Fig. (8):- Ammonium, as N (NH4-N) concentration all over model running process

Nitrate, as $\mathrm{N}(\mathrm{NO} 3-\mathrm{N})$ : Nitrate ions are naturally occurring ions that derived from oxidation (decay) of organic matter as a part of nitrogen cycle. In the environment, different forms of nitrogen $\left(\mathrm{NO}_{2}, \mathrm{NH}_{4}\right.$, and $\left.\mathrm{NH}_{3}\right)$ can transform into nitrate $\left(\mathrm{NO}_{3}^{-}\right)$, which is not dangerous for the health unless it reduced to nitrite $\left(\mathrm{NO}_{2}\right)$. In drinking water, nitrate is measured either in terms of nitrogen present (the permissible level is 10 $\mathrm{mg} / \mathrm{l}$ nitrate-N) or in terms of both nitrogen and oxygen (the permissible level is $50 \mathrm{mg} / \mathrm{l}$ nitrateNO3) (WHO, 2008). Drinking water with nitrate above the permissible level may potentially cause health problem especially to infants, as their digestive systems are likely to allow the reduction of nitrate to nitrite, which reacts directly with the hemoglobin in human blood and other warmblooded animals and produce met hemoglobin. Met hemoglobin destroys the ability of red blood cells to bind with and transport oxygen and causes methaemoglobinaemia (blue baby syndrome) disease. Our study revealed that throughout model running process, the concentrations of Nitrate nitrogen were much lower than the permissible level with mean of $8.42 \mathrm{mg} / \mathrm{L}$ and the concentration decreases (with time) following the equation $\quad \mathrm{y}=-0.0003791 \mathrm{X} 2-0.1501 \mathrm{X}+16.34$

(Figure 9) suggesting that septic tanks of study area has no negative effect on the quality of drinking water with reference to Nitrate nitrogen. 


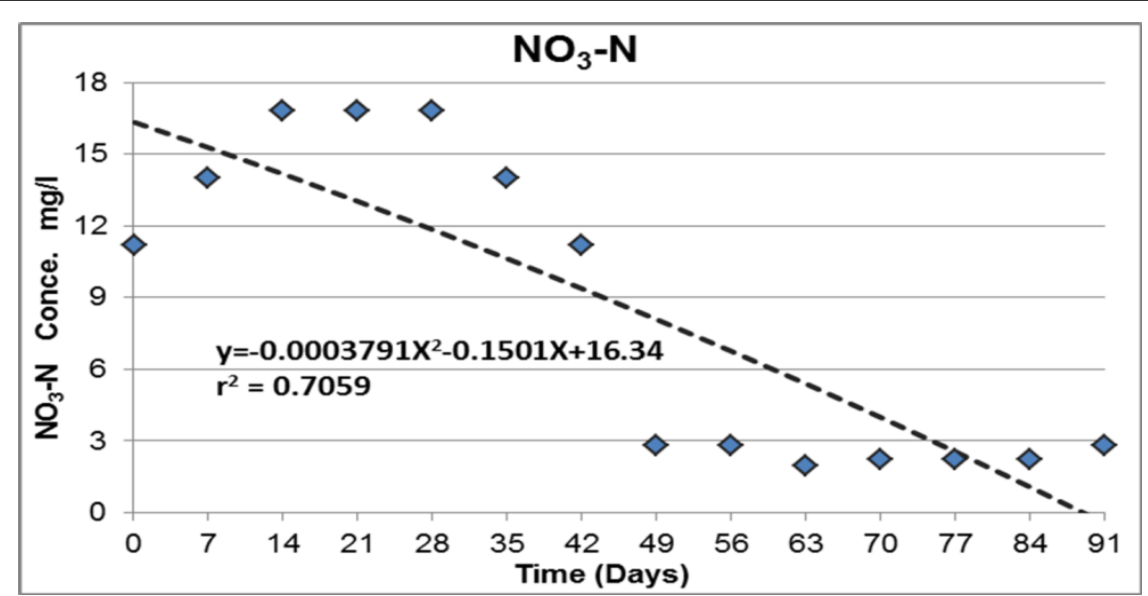

Fig.(9): Nitrate, as N (NO3-N) concentration all over model running process

Phosphorus: Is a non-metallic highly reactive element that is essential for life and found in rocks as inorganic phosphates typically in the form of orthophosphate ions $\left(\mathrm{PO}_{4}^{3-}\right)$ (GUIDANCE, C., 2004). As it is highly reactive, it never found as a free element on earth except some highly oxidized minerals containing phosphorus as inorganic phosphate rocks. In its elemental form, phosphorus is very toxic and is subject to bioaccumulation. In surface water, phosphorus ions originate mainly from sewage effluents, agricultural effluents and industrial effluents (Twort, A. et al, 2000). In agricultural systems, Phosphorus is added to soil by using chemical fertilizers, manure, and composted materials. Phosphorus is capable to largely retain in the soil by adsorption process, but once the limited capacity of soil to adsorb (store) phosphorus is exceeded, the excess will dissolve and move more freely with water either directly to a stream or downward to an aquifer. Long-term overapplication of manure and chemical fertilizer contributes to phosphorus movement into the ground water system resulting in potential contamination. World Health Organization recommends a limit of $5 \mathrm{mg} / \mathrm{L}$ for phosphate which, is equivalent to $1.63 \mathrm{mg} / \mathrm{L}$ of total phosphorus as the total phosphorus $\mathrm{P}=0.3262 \mathrm{x}$ total phosphate $\left(\mathrm{PO}_{4}\right)$. However, (USEPA, 1986) has recommended no more than $0.025 \mathrm{mg} / \mathrm{L}$ for total phosphorus in reservoirs used for drinking water (Oram, 2017). Our study revealed that throughout model running process, the concentrations of total phosphorus were lower than the level recommended by (WHO) with mean of $0.216 \mathrm{mg} / \mathrm{L}$. However, the concentration increases with time following the equation $\mathrm{y}=0.0001354 \mathrm{X}^{2}-0.00595 \mathrm{X}+0.09864$

(Figure 10), and it will reach the maximum level (of $1.63 \mathrm{mg} / \mathrm{L})$ in about 130 days.

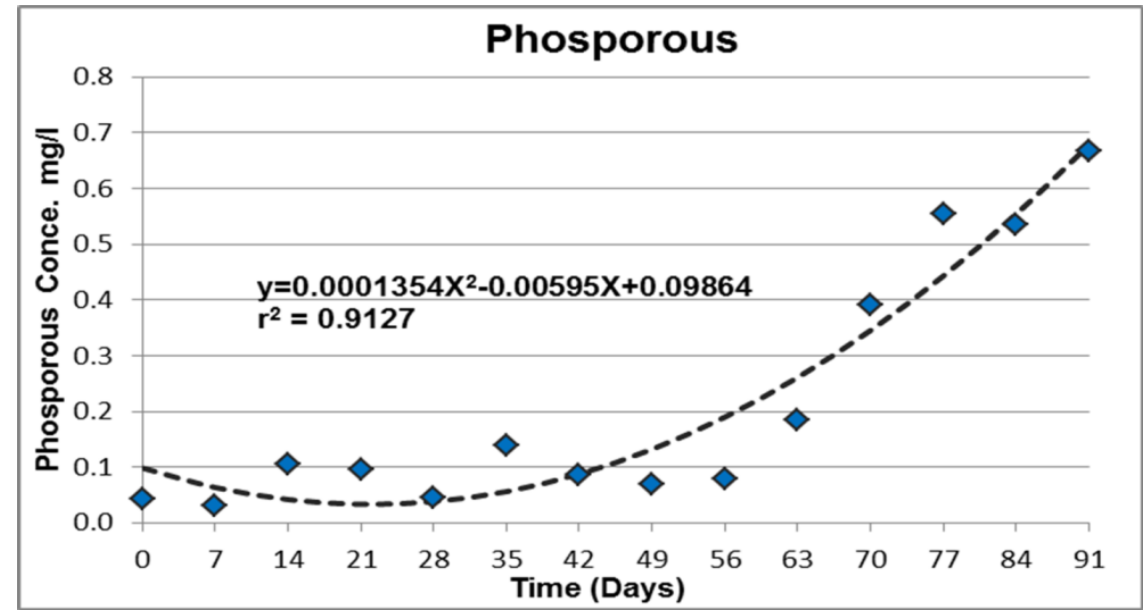

Fig. (10): Phosphorus concentration all over model running process

\section{CONCLUSION}

Based on the current investigation, It was found that septic tanks have a big impact on the 
quality of ground water located at $31.25 \mathrm{~m}$ underground. This water is harmful to human if used for drinking purposes. However, it fits other domestic purposes. The present study showed that except for ammonium nitrogen and nitrate nitrogen, all other investigated parameters including Electrical Conductivity, Total Hardness, Phosphorus and Dissolved Oxygen were above the permissible limits of WHO standards. Dissolved Oxygen has showed an alarming pollution signs suggesting that septic tanks of studied area are to be regulated immediately for improvement.

\section{REFERENCES}

- American Public Health Association, American Water Works Association, Water Environment Federation.(1996). Standard methods for the examination of water and wastewater, 19th ed.; Clesceri, L.S., Eaton, A.D., Greenberg, A.E., Franson, M.A.H., Eds., Washington, DC, USA.

- Bertram, G. E. (1940). An experimental investigation of protective filters.

- Brindha, K., \& Elango, L. (2011). Hydrochemical characteristics of ground water for domestic and irrigation purposes in Madhuranthakam, Tamil Nadu, India. Earth Sciences Research Journal, 15(2), 101-108.

- Das, B. M. (2013). Advanced soil mechanics. CRC Press.

- Deshpande, S. M., \& Aher, K. R. (2012). Evaluation of ground water quality and its suitability for drinking and agriculture use in parts of Vaijapur, District Aurangabad, MS, India. Research Journal of Chemical Sciences, ISSN, 2231, $606 X$.

- GUIDANCE, C (2004). Canadian Water Quality Guidelines for the Protection of Aquatic Life.

- Holland, J. P. (1992). Development of a Comprehensive Modeling System for Remediation of Contaminated Ground water.

- Jadhav, S. D., Jadhav, M. S., \& Jawale, R. W. (2013). Physico-Chemical and Bacteriological analysis of Indrayani River Water at Alandi, Pune District (Maharashtra) India. International Journal of Scientific \& Engineering Research, 4(11).

- Kochary, S. (2017). Ph.D. dissertation “ The impact of septic tanks on the contamination of ground water in upper aquifer of Duhok city " University of Duhok, Kurdistan Region, Iraq.

- Korzoun, V. I., \& Sokolov, A. A. (1978). World water balance and water resources of the earth. Water Development, Supply and Management $($ UK)(USA)(Canada)(Australia)(France)(Germa $n y, F R)$.

- Lipponen, M. T., Martikainen, P. J., Vasara, R. E., Servomaa, K., Zacheus, O., \& Kontro, M. H. (2004). Occurrence of nitrifiers and diversity of ammonia-oxidizing bacteria in developing drinking water biofilms. Water Research, $38(20)$, 4424-4434.

- Ministry of Agriculture and Food, British Columbia. 2000. Drain filters and envelopes. Drainage factsheet. No. 541.240-1.
- Missouri Department of Natural Resources, [accessed in Feb 11, 2017 ], Available on https://dnr.mo.gov/env/esp/waterqualityparameters.htm.

- Olsen, S.R., Sommers, L.E. and Page, A.L., 1982. Methods of soil analysis. Part 2. Chemical and microbiological properties of Phosphorus. ASA Monograph, (9), pp.403-430.

- Oram, B. Water Research Center, B.F. Environmental Consultants Inc. [accessed in Feb 10,2017 ], Available on http://waterresearch.net/index.php/phosphates

- Parashar, C., Dixit, S., \& Shrivastava, R. (2006). Seasonal variations in physico-chemical characteristics in upper lake of Bhopal. Asian J. Exp. Sci, 20(2), 297-302.

- Twort, A. C., Ratnayaka, D. D., \& Brandt, M. J. (2000). Water supply. Butterworth-Heinemann.

- USEPA, U. Environmental Protection Agency (1986) Quality criteria for water 1986. EPA 440/5-86001. Office of Water Regulations and Standards, Washington, DC Google Scholar.

- World Health Organization. (1995). Constitution of the world health organization.

- World Health Organization. (2004). Manganese in drinking-water: Background document for development of WHO Guidelines for DrinkingWater Quality.

- World Health Organization. (2006). WHO child growth standards: length/height for age, weightfor-age, weight-for-length, weight-for-height and body mass index-for-age, methods and development. World Health Organization.

- World Health Organization. (2008). World malaria report 2008. World Health Organization.

- Yates, M. V. (1985). Septic Tank Density and Ground- Water Contamination. Ground water, 23(5), 586-591.

- Zaidi, J. \& Pal, A., (2015). Influence of temperature on physico-chemical properties of freshwater ecosystem of Bundelkhand region of Uttar Pradesh, India.

- Zhang, Y. (2011). Introduction to Geostatistics Course Notes. Dept. of Geology \& Geophysics, University of Wyoming. 